\title{
STRATEGI GERAKAN DAKWAH FRONT PEMBELA ISLAM ACEH
}

\author{
Said Fadhlain \\ Program Studi Ilmu Komunikasi, Universitas Teuku Umar \\ Email: syed-0570@yahoo.co.id
}

\begin{abstract}
This study discusses the Strategy of FPI Dakwah Movement in Aceh. The problems studied in this research are formulated in a problem formulation: How is the understanding of the mission movement of FPI in Aceh? How is the strategy of the mission movement of the FPI in Aceh?, What are the opportunities and challenges of the mission movement of the FPI in Aceh? This research is field research with data collection technique through interview technique and documentation study. The research method used is descriptive research method qualitative analysis, which is trying to describe the systematic facts or characteristics of a particular population or specific field in actual and accurate. The results showed, among others: Understanding propaganda movement according to FPI in Aceh, namely amar makruf nahi munkar. FPI is an Islamic organization that Ahlussunnah Waljama'ah (Aswaja) faith who using Imam Syafi'i mazhab and aqidah Asy'ariyah Maturidiyah, and based on bilhikmah, mau'idatul hasanah and mujadalah. Strategy of mission of FPI in Aceh, in addition to seeking new followers, Rely on recruitment of members who come from pengajian participants, jama'ah mosque, or students in boarding schools run by FPI leaders. The mission of FPI by way of hisbah, the demonstration and sweeping of the eradication of immoral place, the dakwah of billisan, bilqalam and bilhal The opportunity of FPI preaching in Aceh has been well known by the community, especially the dayah ulama who give full support to FPI, even some heads of regions Preaching of FPI in Aceh. While the main challenge of FPI preaching in Aceh is the role of mainstream media that tends to exploit the negative side of the reporting of FPI Aceh's activities, the weakness of government and police efforts to enforce the law against the violation of Islamic Sharia in Aceh, as well as the violent FPI dakwah.
\end{abstract}

Keywords: Strategize, Movement, Dakwah, and Front Pembela Islam (Islamic Defenders Front)

\section{PENDAHULUAN}

Perubahan sosial di Aceh terus berlangsung sejalan dengan perkembangan ilmu dan teknologi, bersamaan dengan hal tersebut agama-agama dan idiologi lain mulai menampakkan kegiatannya dengan memberikan pelayanan yang konkrit kepada masyarakat, sehingga masalah yang dihadapi dakwah Islam semakin komplek berkaitan dengan berbagai permasalahan sosial, politik, ekonomi, pendidikan, ilmu pengetahuan dan teknologi.

Islam sebagai sebuah keyakinan umat manusia dalam menjalani kehidupan dunia maupun akhirat, merupakan agama yang dinamis, konstruktif, responsif dan universal. Dalam perspektif Islam tidak mengenal adanya dikotomi antara fungsi kehidupan dunia dan akhirat, keduanya memiliki dimensi "ubudiyah yang sama.

Problematika kehidupan yang sangat bervariasi telah banyak memunculkan berbagai peristiwa yang perlu ditangani misalnya dekadensi moral di kalangan remaja, narkotika, 
menjalarnya korupsi, kolusi dan sebagainya yang mengarah rendahnya nilai moral pada manusia. (Jasafat, 2013)

Dengan munculnya kenyataan sosio kultural tersebut, harus menimbulkan kesadaran baru di kalangan pemeluk Islam untuk lebih mensistematiskan dakwahnya dalam berbagai bidang kehidupan, agar dakwah Islam dapat berkembang sesuai dengan perkembangan dan kebutuhan zaman. (Achmad Amrullah, 1983). Dampak perubahan sosio-kultural yang terjadi menyentuh langsung lembaga atau organisasi dakwah yang ditandai dengan ketidakmampuannya melihat masalah secara jelas, tema dakwah yang tidak mengikuti arah zaman sudah mulai kehilangan relevansinya, sedangkan model dakwah yang ada sudah tak dapat digunakan untuk melihat dan memecahkan masalah yang semakin rumit.

Permasalahan fundamental yang dihadapi oleh gerakan dakwah Islam adalah tidak adanya perencanaan kerangka dakwah yang disusun secara sistematis dan utuh untuk merealisasikan Islam dalam semua dataran kehidupan, dimana dakwah Islam yang dilakukan oleh masih bersifat parsial.

Keberadaan organisasi kemasyarakatan sosial dan keagamaan (Islam), khususnya gerakan dakwah, di tengah-tengah kehidupan umat Islam, memiliki peran strategis bersama-sama dengan peran ulama dan umara dalam dakwah memajukan pemahaman terhadap ajaran Islam. Peran ini dijalankan secara sinergi dalam rangka mencapai tujuan dakwah. (Achmad Amrullah, 1983)

Oleh karena itu, gerakan dawah juga berperan dalam rangka terbinanya kehidupan yang rukun dan damai, taat dalam melaksanakan ajaran agama dan memiliki kepedulian sosial yang tinggi. Lebih dari itu, diharapkan munculnya sikap saling menghormati satu sama lain, baik sesama muslim maupun dengan pemeluk agama lainnya.(Abdullah, 2002)

Kebebasan dakwah di Indonesia, khususnya Aceh tidak terlepas dari perjuangan para ulama dan Umat Islam yang sejak zaman penjajahan hingga kini, tidak henti-hentinya melakukan perlawanan terhadap segala bentuk upaya yang ingin mematikan dakwah Islam.

Gerakan dakwah FPI merupakan salah satu organisasi di Indonesia dan keberadaannya di Aceh berupaya menjalankan dakwahnya dengan strategi yang dapat menggugah hati masyarakat dan memerlukan upaya yang sungguh-sungguh dan terorganisir secara rapi. Proses ini merupakan suatu perubahan dari sistem merasa, berfikir, bersikap dan bertindak individu dan masyarakat menuju pembangunan dan penciptaan realitas sistem baru yang menjunjung tinggi nilai-nilai kemanusiaan, keadilan, kebenaran, perdamaian, keindahan, kebaikan dan lain sebagainya yang disebut sebagai realitas islami.

Kehadiran FPI ini menjadi suatu fenomena sosial yang patut dicermati. Karenanya, perlu diadakan satu penelitian khusus yang akan mengungkapkan dan menganalisis mengenai keberadaan FPI secara detail, agar kontraversi di mata masyarakat mendapat jawaban tuntas dan dapat dijadikan satu rujukan. (Zuly Qodir, 2008)

Menurut para aktivis FPI, pemerintah tidak dapat mengendalikan terjadinya tindak kemaksiatan di masyarakat. Hal itu terbukti dengan maraknya praktik perjudian, narkoba, minuman keras, dan beroperasinya tempat-tempat maksiat secara terbuka. Oleh karena pemerintah tidak bersikap tegas terhadap masalah kemaksiatan maka umat Islam, menurut kelompok ini, berkewajiban mengambil inisiatif membantu pemerintah untuk memerangi kemaksiatan tersebut.(Al- Zastrouw, 2006)

Keberadaan FPI hampir selalu dikaitkan dengan aksi-aksi penyisiran, penyerangan dan pengrusakan tempat-tempat yang dianggap sebagai sumber kemaksiatan, yakni diskotik, tempat-tempat prostitusi, bar dan karaoke, tempat perjudian dan sebagainya. (M Zaki Mubarok, 2008). Gerakan dakwah FPI bukan berarti tanpa maqal melainkan lebih ditekankan pada sikap prilaku dan kegiatan-kegiatan nyata yang secara interaktif 
mendekatkan masyarakat pada kebutuhannya yang secara langsung atau tidak langsung dapat mempengaruhi peningkatan kualitas keimanan. (Abul Karimi, 2003)

Oleh karena itu, keberadaan organisasi FPI di Aceh, dengan gerakan dakwahnya diharapkan memberikan peran positif dan strategis. Khususnya dalam melakukan kegiatan dakwah serta bersinergi dengan stake-holder lainnya dalam upaya menegakkan syariat Islam di seluruh pelosok bumi Aceh, sebagaimana yang diamanatkan dalam qanun pemerintah Aceh. Dalam hal ini penulis tertarik dengan gerakan dakwah FPI, sehingga melakukan penelitian yang dirangkai dalam sebuah judul penelitian "Strategi Gerakan Dakwah Front Pembela Islam di Aceh"

\section{KAJIAN LITERATUR}

\section{Gerakan Dakwah}

Studi gerakan sosial sebagai kajian tentang perubahan sosial dalam perkembangannya mengalami kemajuan yang pesat. Sejak lima dasa warsa terakhir, studi ini tidak lagi dimonopoli oleh ilmu siosiologi, tetapi berkembang menjadi bagian integral dari ilmu sosial lainnya.

Untuk memahami fenomena gerakan sosial dan ketegangan sosial yang terjadi di dalam suatu masyarakat, Eisinger menggunakan teori Political Oppurtinity Structure atau Struktur Kesempatan Politik. Teori ini menjelaskan bahwa gerakan sosial terjadi karena disebabkan oleh perubahan dalam struktur politik yang dilihat sebagai kesempatan. (Abdul Wahid Situmorang, 2011)

Dakwah merupakan aktualisasi atau realisasi salah satu fungsi kodrati seorang muslim, yaitu fungsi kerisalahan berupa proses pengkondisian agar seseorang atau masyarakat mengetahui, memahami, mengimani dan mengamalkan Islam sebagai ajaran dan pandangan hidup (way of life).

Dakwah adalah suatu upaya untuk merubah suatu keadaan menjadi keadaan lain yang lebih baik menurut tolok ukur ajaran Islam sehingga seseorang atau masyarakat mengamalkan Islam sebagai ajaran dan pandangan hidup. Dengan kata lain tujuan dakwah, setidaknya bisa dikatakan, untuk mempertemukan kembali fitrah manusia dengan agama atau menyadarkan manusia supaya mengakui kebenaran Islam dan mengamalkan ajaran Islam sehingga benar-benar terwujud kesalehan hidup. (Sukriyanto, 2002)

Aktivitas dakwah dapat dilakukan dengan berbagai cara dan direncanakan dengan tujuan mencari kerizaan hidup dengan dasar kerizaan Allah S.w.t. Dakwah adalah usaha peningkatan pemahaman keagamaan untuk mengubah pandangan hidup, sikap batin dan perilaku umat sesuai dengan ketentuan syariat untuk memperoleh kebahagiaan hidup di dunia dan akhirat. Dai harus mempunyai pemahaman yang mendalam, bukan saja menganggap bahwa dakwah dalam frame "amar ma'ruf nahi mungkar" atau sekedar menyampaikan saja, melainkan harus memenuhi beberapa syarat, yakni mencari materi yang cocok, mengetahui kondisi psikologis obyek dakwah, memilih metode yang representatif, menggunakan bahasa yang bijaksana dan sebagainya. Secara konvensional, subjek dakwah terdiri dari dai (mubaligh) dan pengelola dakwah. (Suparta, 2003).

\section{Strategi Dakwah}


Strategi merupakan istilah, sering diidentikkan dengan "taktik" yang secara bahasa dapat diartikan sebagai "corcerning the movement of organisms in respons to external stimulus" (suatu yang terkait dengan gerakan organisme dalam menjawab stimulus dari luar). Sementara itu, secara konseptual strategi dapat dipahami sebagai suatu garis besar haluan dalam bertindak untuk mencapai sasaran yang telah ditentukan. Strategi juga bisa dipahami sebagai segala cara dan daya untuk menghadapi sasaran tertentu dalam kondisi tertentu agar memperoleh hasil yang diharapkan secara maksimal. (Awaluddin Pimay, 2005)

Dengan demikian, strategi dakwah dapat diartikan sebagai proses menentukan cara dan daya upaya untuk menghadapi sasaran dakwah dalam situasi dan kondisi tertentu guna mencapai tujuan dakwah secara optimal. Dengan kata lain strategi dakwah adalah siasat, taktik atau manuver yang ditempuh dalam rangka mencapai tujuan dakwah.

\section{Metode Penelitian}

Berdasarkan objek masalah yang dikaji yaitu: "Strategi Gerakan Dakwah Front Pembela Islam di Aceh" maka penting dilakukan metode apa yang digunakan. Penelitian ini adalah penelitian lapangan dengan teknik pengumpulan data melalui teknik wawancara, kepustakaan dan dokumentasi. Sedangkan metode penelitian yang digunakan adalah metode penelitian bersifat deskriptif analisis kualitatif, yaitu berusaha untuk melukiskan secara sistematis fakta atau karakteristik populasi tertentu atau bidang tertentu secara faktual dan cermat. Metode deskriptif adalah adalah suatu metode penelitian yang cara pemecahan masalahnya dengan menggambarkan keadaan suatu objek berdasarkan faktafakta yang ada di lapangan (Moeleong, 2009: 6).

Penelitian ini langsung dilakukan oleh peneliti melalui pengamatan dan wawancara dengan dibekali teori-teori dan konsep dalam melihat fenomena di lapangan atau masyarakat. Sehingga peneliti dapat memperoleh sebanyak mungkin informasi serta dapat menginterpretasikan gejala sosial di dalam masyarakat yang akan diteliti (Usman, 2009:121).

Adapun objek penelitian ini adalah organisasi FPI Aceh. Sumber data adalah mereka yang dapat memberikan informasi tentang objek penelitian. Dalam penelitian ini yang menjadi nara sumber adalah pimpinan dan pengurus FPI, baik ditingkat pusat, wilayah, daerah, serta pihak instansi lain seperti Dinas Syariat Islam, Majelis Permusyawaratan Ulama (MPU) dan Walikotamadya Banda Aceh yang mendukung pelaksanaan syariat Islam di Aceh.

Penelitian ini juga bersifat deskriptif analisis kualitatif, yaitu berusaha untuk melukiskan secara sistematis fakta atau karakteristik populasi tertentu atau bidang tertentu secara faktual dan cermat (Rahmat, 2004: 7).

Metode deskriptif adalah suatu metode penelitian yang cara pemecahan masalahnya dengan menggambarkan keadaan suatu objek berdasarkan fakta-fakta yang ada di lapangan. Untuk mendeskripkan kata-kata pada permulaan tertuju pada usaha untuk mengemukakan gejala secara lengkap dalam aspek yang diteliti. Kemudian dikembangkan dengan memberikan interpretasi terhadap fakta yang ditemukan. Metode ini tidak terbatas pada pengumpulan dan penyusunan data, tetapi meliputi analisa dan interpretasi tentang arti data itu (Hadi, 1987: 3). 


\section{HASIL PEMBAHASAN}

\section{Gambaran Umum tentang FPI Aceh.}

Paska tumbangnya pemerintahan Orde Baru tahun 1998, diwarnai dengan munculnya aktor "Gerakan Islam Baru" (New Islamic Monement) Aktor baru ini berbeda dengan aktor gerakan Islam lama, seperti NU, Muhammadiyah, Persis, Al-Irsyad, Al-Wasliyah, Jama'at Khair dan sebagainya. Organisasi gerakan Islam baru ini memiliki basis ideologi, pemikiran dan strategi gerakan yang berbeda dengan ormas-ormas Islam sebelumnya, memiliki karakter yang lebih militan, radikal, skripturalis, konservatif, dan ekslusif, dengan visi dan misi mewujudkan penerapan syari'at Islam di Indonsia. Secara keseluruhan kelompok ini menganut paham "salafisme radikal", yakni berorientasi pada penciptaan kembali masyarakat salafi (generasi Nabi Muhammad dan para sahabatnya), dengan caracara keras dan radikal. Bagi kelomppok ini Islam pada masa kaum salafi inilah merupakan Islam paling sempurna, masih murni dan bersih dari berbagai tambahan atau campuran (bid'ah) yang dipandang mengotori Islam. (M Imaduddin Rahmad, 2005).

Hasil penelitian Litbang Kompas (1999), menjelaskan bahwa era reformasi merupakan momentum bangkitnya gerakan Islam di Indonesia, dimana kondisi sosial politik yang makin terbuka dan melemahnya peran Negara membuat kelompok Islam memiliki keleluasaan dalam menyuarakan aspirasi dan ekspresinya. Selain menggugat secara terbuka tentang keabsahan pancasila sebagai asas tungga, kelompok gerakan islam juga mengekspresikan ajaran Islam melalui simbol-simbol formal. (Nurotul Badriyah, 2014)

Selanjutbya, momentum sejarah pendirian organisasi FPI terjadi hanya empat bulan setelah Presiden Soeharto mundur dari jabatannya (21 Mei 1998), karena pada saat pemerintahan Orde Baru presiden tidak mentoleransi tindakan ekstremis dalam bentuk apapun. FPI pun berdiri dengan tujuan untuk menegakkan hukum Islam di negara sekuler. Lemahnya kondisi penegakan hukum dan pemerintah pada awal pelaksanaan era reformasi di tahun 1998, dimanfaatkan oleh sekelompok "mafia", yang tediri dari LSMLSM yang berupaya merusak negara melalui cara sistematis dengan menyebarkan berbagai macam kemunkaran. Hal itulah yang mendorong para ulama, habâib, dan kiai begitu antusias untuk mendirikan suatu organisasi amr ma 'rûf nahy munkar. (Saiful Anwar, 2014).

Kehadiran FPI sebagai salah satu dari berbagai organisasi masyarakat Islam, dalam perkembangannya telah tersebar di berbagai daerah di Indonesia. Organisasi FPI terbentuk dari jenjang tingkat Pusat (DPP), Provinsi (DPD), Kabupaten/Kota (DPW), Kecamatan (DPC) hingga Desa/Gampong (POSKOMANDO). Awal mula terbentuknya FPI Aceh, tepat setelah beberapa hari terjadinya peristiwa gempa dan gelombang tsunami pada tanggal 26 Desember 2004. Koran Tempo, menuliskan berita tentang adanya relawan kemanusiaan FPI dengan memakai kaos oblong putih, bertuliskan "Duka Aceh, Duka Kita Semua", bersama relawan kemnusiaan dari ormas Islam lainnya mendirikan posko-posko di Masjid Raya Baiturrahman. (Koran Tempo, 2005)

Momentum terbentuknya FPI Aceh, ketika pada tanggal 27 Oktober 2008 saat berlangsungnya Musyawarah Daerah Pertama Pembentukan FPI Aceh di dayah Teungku Nasruddin Judon (anggota DPRK Fraksi Partai Aceh periode tahun 2009-2014). Acara yang dihadiri sekitar 150 orang peserta, antara lain kalangan pimpinan dayah pesantren dari beberapa kabupaten, perwakilan mahasiswa, serta unsur masyarakat lainnya, telah berhasil memilih Yusuf Al- Qardhawi sebagai Ketua Umum DPD FPI Aceh, Periode 2008-2013.

Menurut Yusuf Al- Qardhawi, sejak terbentuknya kepengurusan DPD FPI Aceh tahun 2008 silam, hingga sekarang ini telah pua terbentuk DPW di 22 kabupaten/kota yang 
ada di Aceh, minus kabupaten Aceh Tenggara dan Simeulu. Menurut Yusuf Al- Qardhawi, organisasi FPI Aceh (DPD FPI), memiliki struktur organisasi yang sama dengan FPI Pusat (DPP FPI), sebagaimana dijelaskan sebelumnya bahwa struktur kepemimpnan organisasi terdiri dua komponen yaitu Dewan Tanfidzi dan Majelis Syura. Majelis Syura merupakan Dewan Tertinggi Front.Sebagai, sementara dewan Tanfidzi merupakan pengurus harian. Untuk keanggotaan organisasi, FPI Aceh juga memiliki keanggotaan jamaah FPI dan keanggotaan laskar FPI. (Wawancara, Tengku Yusuf Qardhawi)

Jika dilihat dari komposisi kelas sosialnya, berdasarkan beberapa penelitian seperti yang dilakukan Jajang Jahroni (2004:201-244) terhadap FPI, penelitian Yunanto, S., dkk. 2003 tentang Gerakan Militan Islam di Indonesia dan di Asia Tenggara dapat dipetakan secara sosiologis kelas sosial pengikut gerakan Islam garis keras. Dalam kasus FPI, pada level elit diisi oleh mereka dari kalangan habaib, kemudian pada level menengah diisi oleh kalangan menengah dan terpelajar (terutama dari perguruan tinggi umum). Sedangkan pengikut terbesar dari FPI yang berada pada bagian bawah piramida adalah dari kalangan masyarakat kebanyakan yang secara ekonomi dan pendidikan dapat dikategorikan wong cilik. (Eka Hendry, 2013)

Hasil amatan peneliti, terlihat adanya karakteristik kepengurusan FPI Aceh baik pada level Majelis Syura maupun Dewan Tanfidzi diisi oleh orang-orang yang memiliki unsur yang berbeda dengan DPP FPI, terutama oleh kalangan pimpinan dayah pesantren, kalangan intelektual kampus, serta unsur masyarakat lainnya. Komposisi kepengurusan organisasi FPI Aceh pada periode pertama (tahun 2008-2012), sementara pada periode kedua (tahun 2012-2017), didominasi oleh kalangan pimpinan dayah pesantren. Sementara dari kalangan habaib di Aceh, tidak terakomodir dalam komposisi dewan syura maupun dewan tanfidzi.(Wawancara, Teungku Al- Hijrah).

\section{Pemahaman Gerakan Dakwah menurut FPI Aceh}

Berdasarkan hasil penelitian, dapat dikemukakan bahwa Front Pembela Islam (FPI) merupakan organisasi Islam yang beraqidah Ahlussunnah Waljama'ah (Aswaja) yang bermazhab Imam Syafi'i dan beraqidah Asy'ariyah dan Maturidiyah'ah. Organisasi in didirikan pada tanggal 17 Agustus 1998 di Pondok Pesantren Al-Umm Ciputat, Jakarta. Di antara tokoh pendirinya adalah para ulama yang terdapat di Jakarta dan sebagian para habaib. Inisiatif lahirnya ormas ini pada dasarnya karena maksiat terus meralela di Jakarta dan sekitarnya. Maksiat dilakukan secara tersistem, maka diperlukan organisasi Islam yang tersistem pula, "alhaqqu bighairi nidhamin yughlibul bathil binnidhamin" (kebenaran yang tidak terorganisir dapat dikalahkan oleh kebatilan yang teroranisir).

Mengenai pemahaman gerakan dakwah FPI di Aceh dapat dilihat dari prosedur gerakan yang diterapkan oleh FPI, yaitu wilayah amar makruf dan wilayah nahi munkar. Pertama, merupakan wilayah sarang maksiat. Kedua, yang merupakan suatu wilayah sarangnya kaum santri atau di dalamnya ditekankan pentingnya nilai keagamaan, maka tindakan yang paling baik adalah dengan melakukan tindakan preventif.

\section{Aplikasi Konsep Gerakan Dakwah FPI Aceh.}

Konsep Amar Ma'ruf dan Nahy Munkar merupakan dua konsep utama gerakan dakwah FPI. Setiap aktifitas dakwah yang dilakukan oleh anggota FPI (Pengajian Jamaah dan Aksi di Jalanan Laskar FPI) senantiasa memiliki keterikatan dengan konsep dakwah 
tersebut. Secara etimologi, amr ma'ruf nahi munkar merupakan kata dari bahasa arab yang telah digunakan dalam perbendaharaan kosa kata bahasa Indonesia, yang artinya melaksankan perintah yang baik dan mencegah perintah yang buruk. Secara terminologi, al- amr bi al- ma'ruf memiliki makna perintah untuk melakukan segala perkara yang baik menurut hukum syara' dan hukum akal. Sedangkan nahi munkar adalah mencegah setiap kejahatan/kemungkaran, yakni setiap perkara yang dianggap buruk oleh syara' dan hukum akal.

Pelaksanaan konsep dakwah Amr Ma'ruf dan Nahu Munkar FPI memiliki pedoman dengan beberapa mekanisme, antara lain :

1. Kasus amar ma'ruf anhi munkar yang akan diperjuangkan terlebih dahulu harus dikaji berdasarkan syariat Islam oleh para ahlinya.

2. Kasus diusahakan diselesaikan terlebih dahulu dengan menempuh prosedur hukum formal negara yang berlaku, melalui :

a. Menghimpun fakta sebagai bukti hukum

b. Menghimpun dukungan konkrit masyarakat sekitar

c. Pelaporan dan tuntutan ke seluruh instansi negara yang berwenang

3. Penggunaan dan pemanfaatan kekuatan umat saat prosedur menemui jalan buntu

Bila prosedur hukum formal negara menemui jalan buntu dan bila penegakan ama ma'ruf nahi munkar sudah mesti ditegakkan, dan bila berbagai pertimbangan sudah dilakukan dengan cermat dan sesuai syariat, maka FPI akan mengambil tindakan tegas dengan melibatkan segenap komponen umat.

Aplikasi konsep dakwah FPI adalah dengan menegur pihak-pihak yang melanggar syariat, baik dengan cara hisbah maupun dengan aksi demonstrasi dan pemberantasan tempat maksiat, penegakan dakwah billisan, bilqalam dan bilhal. FPI tidak menafikan prosedur hukum formal negara. Karena prosedur ini mutlak karena diakui hal tersebut merupakan domain pemerinta atau aparat keamanan. Tetapi apabila pemerintah tidak meresponny, setelah mengirim beberapa kali surat peringatan dan teguran, FPI akan turun dengan kekuatan laskar militannya.

Anggaran Dasar dan Rumah Tangga (AD/ART) FPI disebutkan bahwa latar belakang berdirinya FPI adalah sebagai: Pertama, penderitaan panjang umat Islam di Indonesia karena lemahnya kontrol sosial penguasa sipil maupun ABRI, akibatnya banyak pelanggaran HAM yang dilakukan oleh oknum penguasa. Kedua, adanya kewajiban untuk menjaga dan mempertahankan harkat dan martabat Islam serta umat Islam. Oleh karena itu, tujuan umum didirikannya FPI adalah untuk membangkitkan ruhul jihad dan menegakkan amar ma'ruf nahi munkar dalam ikatan ukhuwah Islamiyah. (Wawancara, Teungku Muslim Ath- Thahiry).

Ruhul jihad, secara etimologis adalah menuangkan segenap kemampuan agar tercapai segala kebaikan menurut Allah S.w.t. serta Nabi muhammad S.a.w. Konsep ini ada dalam segala lini, misalnya orang yang sedang menuntut ilmu di perguruan tinggi, juga termasuk jihad ilmu dengan segala pengorbanannya. Orang datang berdemonstrasi atau unjuk rasa (dzahirina alal haq) membela Islam, bahkan mencari nafkah keluarga termasuk jihad. (Habib Myhammad Rizieq, 2008)

Saat munculnya isu tentang keberadaan aliran sesat Gerakan Fajar Nusantara (GAFATAR). Front Pembela Islam (FPI) Aceh melakukan orasi di bundaran Simpang Lima, Banda Aceh pada Selasa, 22 Rabiul Awal atau 13/01/2015. Dalam aksinya FPI Aceh meminta ketegasan dari Pemerintah Aceh terhadap orang-orang yang ingin menghancurkan Syariat Islam dan Ahlussunnah Wal Jamaah di bumi Serambi Mekkah. Aliran sesat ini 
diduga merupakan kaki tangan Millata Abraham yang mengakui adanya Nabi setelah Nabi Muhammad saw. diduga sekarang mengganti nama menjadi GAFATAR (Gerakan Fajar Nusantara) yang mencoba memurtadkan masyarakat Aceh. Hal itu dibuktikan setelah kantor DPD GAFATAR digrebek warga Desa Lamgapang, kecamatan Krueng Barona Jaya, Aceh Besar dan mendapatkan sejumlah buku-buku dan dokumen terkait ajaran yang pernah dibawa oleh Millata Abraham. Warga menilai keberadaan organisasi tersebut telah menyimpang dari ajaran Islam dan meresahkan warga.

Selain itu, untuk menyikapi maraknya berita tentang praktek maksiat yang terjadi di Banda Aceh, seperti hotel dan salon, Tgk Yusuf Al- Qardhawi berharap kepada Pemerintah Kota Banda Aceh agar mencabut izin tempat usaha yang melanggar ketentuan syariat Islam, seperti salon atau hotel. Begitupun, dia meminta Satpol PP dan WH Banda Aceh agar berperan aktif dalam mencegah maksiat di Banda Aceh. "Kalau kita lihat sekarang banyak salon yang belum ditertibkan, dan banyak muda-mudi yang suka duduk di tempat remang-remang. Yang sangat disayangkan di Masjid Raya Baiturrahman, ketika magrib masih ada orang duduk di halaman mesjid tidak shalat. Bahkan berpasangpasangan. Inikan hal yang sangat disayangkan dan memalukan Aceh. Untuk menyikapi hal tersebut, Waka Polres Banda Aceh, AKBP Sugeng mengatakan, sangat berharap kepada FPI Aceh, saat melaksanakan penertiban agar tidak arogan. "Ikuti aturan dari mana dimulai startnya. Kalau perlu koordinasikan dengan Satpol PP dan WH Banda Aceh dan Pemerintah Kota. (Harian Serambi, 2015).

\section{Peluang dan Tantangan Gerakan Dakwah FPI Aceh}

Hambatan dan tantangan yang dihadapi FPI dalam mengembangkan gerakan dakwahnya Pertama. Streo-tipe media-massa mainstream yang dikategorikan sebagai phobia Islam yang selalu memberitakan kegiatan dakwah FPI sebagai sebuah gerakan Islam radikal. Sehingga sebagian masyarakat mengklaim FPI keras. Kedua, Pelaku maksiat dibekengi oleh oknum-oknum berkuasa. Dan Ketiga, masyarakat yang apatis. Tidak peduli dan tidak juga mendukung. (Wawancara, Teumgku Mustafa Husen Woyla).

Tantangan utama yang dihadapi FPI Aceh, terkait dengan pemberitaan media mainstream yang cenderung mengeksploitasi sisi negatif terhadap aktifitas dakwah FPI, sehingga sedikit banyaknya ikut mempengaruhi kehadiran dakwah FPI Aceh. Pemberitaan yang dilakukan oleh media mainstream tersebut lebih menonjolkan kegiatan-kegiatan sweeping atau razia oleh Laskar FPI dan Laskar Pembela Islam (LPI) terhadap praktek maksiat ditengah-tengah masyarakat, terutama pemberitaan pada bulan-bulan ramadhan. Ini berbanding terbalik, bilamana FPI dan juga FPI Aceh melakukan dakwah amar ma'ruf ditengah-tengah masyarakat, misalnya bantuan kemanusiaan, ini jarang dan bahkan tidak terekspos oleh media tersebut. Adapun tantangan gerakan dakwah FPI Aceh lainnya adalah dari sisi penegakan hukum, baik Polri, TNI dan pemerintah sepertinya kurang serius dalam melaksanakan penerapan syariat Islam termasuk belum semua aspek syariat diatur dalam qanun syariat Islam.

Tantangan lain juga dihadapi FPI Aceh, dimana masyarakat yang memiliki apatisme, yaitu tidak peduli dan tidak mendukung. Walaupun sesungguhnya, masyarakat bukan menjadi hambatan di Aceh karena sebagian besar masyarakat Aceh mendukung gerakan dakwah FPI. Selama ini setiap aksi FPI baik di Banda Aceh maupun di luar Banda Aceh, swadaya masyarakat cukup besar. Selain menyediakan fasilitas, masyarakat juga ikut serta bergabung dengan aksi-aksi FPI dan bahkan menyediakan makanan. Hal ini terlihat misalnya ketika perjuangan Qanun Jinayah pada 27 September 2014, di mana hampir 1000 orang massa FPI selama 2 hari 2 malam membuka posko di Komplek Makam Syiah Kuala, masyarakat Banda Aceh dan Aceh Besar secara swadaya mengantar makanan dan 
minuman untuk menyukseskan perjuangan Qanun Jinayah tersebut, dan pada 22 Oktober 2014, Qanun Jinayah disahkan oleh DPR Aceh.

Peluang dakwah FPI Aceh terlihat dari diterimanya keberadaan ditengah-tengah masyarakat, khususnya masyarakat sayah atau santri. Terlihat jelas dari komposisi kepengurusan baik di level wilayah/provinsi (DPW), daerah/kabupaten (DPD), cabang/kecamatan (DPC), serta level ranting yaitu gampong atau desa. Selain itu juga adanya dukungan positif dari stake holder, khususnya aparat keamanan dan kepolisian, serta aparatur pemerintah provinsi dan kabupaten,misalnya dalam kegiatan tabligh akbar maupun acara keagamaan lainnya. Kerjasama FPI Aceh dengan berbagai organisasi masyarakat yang bergerak dibidang dakwah, telah terjalin baik, khususnya ormas dakwah yang berafiliasi dengan dayah atau pondok pesantren.

\section{Strategi Dakwah FPI Aceh.}

Strategi dakwah FPI Aceh, selain untuk mencari pengikut baru, FPI bersandar pada rekruitmen anggota yang berasal dari peserta pengajian, jama'ah masjid, mahasiswa ataupun santri di pondok pesantren yang dikelola oleh tokoh FPI dan di dalam dakwahnya menggunakan teori tebang pohon. Artinya sebelum berhasil misi dakwahnya tidak akan berhenti. Perjuangan FPI konsisten, di mana sebelum misi yang satu berhasil, tidak akan pernah menyerah. Segala resiko siap ditanggung oleh FPI. Hal ini dapat dilihat dari Mottonya, "Di penjara berarti "uzlah, di buang berarti tamasya, dan dibunuh berarti syahid."

Sejalan dengan strategi dakwah FPI di Aceh, organisasi tersebut di Aceh memang pada awal berdirinya, untuk mencari pengikut baru, FPI bersandar pada rekrutmen anggota yang berasal dari peserta pengajian, jama'ah masjid, ataupun santri di dayah/pondok pesantren yang dikelola oleh tokoh FPI. Ibarat sebuah mesjid, siapapun yang datang ke mesjid itulah jamaah masjid.

Seluruh aktivitas FPI ditangani secara langsung dan dikomandoi oleh ketua umum. Dengan tidak adanya mekanisme organisasi yang jelas maka ketua umum FPI memiliki otoritas penuh untuk mengambil inisiatif dan kebijakan. Sebagai organisasi yang berorientasi pada gerakan agama, maka gerak dan langkah organisasi harus berada di bawah kendali langsung pemimpin. Dalam hal ini, seluruh pengikut FPI diberikan doktrin bahwa pemimpin mereka adalah para haba'ib dan ulama ynag merupakan cerminan dari orang-orang suci yang mendapat legitimasi agama. Karena itu mereka tidak boleh ditentang, harus ditaati, dan perkataannya harus dilaksanakan. Barang siapa yang menentang perintah dan perkataan pemimpin maka dia digolongkan sebagai bughat (penentang agama), dan berhak mendapat hukuman. (Al- Zastrouw, 2006).

Begitu pula halnya FPI Aceh, dimana seluruh aktifitas kegiatan dakwahnya, posisi ketua umum FPI memiliki tanggung jawab dan otoritas penuh. Memang pada tahapan perencanaan selalu melibatkan unsur Dewan Syura dan Imam FPI Aceh. Namun demikian, wewenang segala keputusan yang dilakukan sepenuhnya dimiliki oleh ketua umum FPI Aceh. (Wawancara, Teungku Al- Hijrah).

\section{Persamaan dan Perbedaan Gerakan Dakwah FPI Aceh}

Sebagaimana dijelaskan dalam dokumen Risalah historis dan garis perjuangan FPI, asas FPI adalah Islam ala Ahlussunah wal Jama'ah (Aswaja). "FPI menggunakan faham Ahlussunnah Wal Jama'ah, seperti ahlussunnah Aswaja FPI memiliki perbedaan yang mendasar dengan ormas Islam lainnya, termasuk NU. 
Penegasan hal tersebut diperkuat dalam buku Ja'far Umar Thalib, Mengenal Sejarah Ahlussunah Wal Jama'ah bahwa Aswaja yang dipahami FPI tidaklah sama dengan yang difahami oleh kalangan NU maupun Muhammadiyah. Aswaja yang dipahami para aktivis FPI lebih mendekati pemahaman Aswaja menurut kelompok Salafi yang dipimpin oleh Ustadz Ja'far Umar Thalib di Yogyakarta. Menurut kelompok ini, Aswaja adalah mereka yang telah sepakat untuk berpegang dengan kebenaran yang pasti sebagaimana tertera dalam al-Qur'an dan al-Hadist dan mereka itu adalah para sahabat dan tabi'in (orang yang belajar dari sahabat dalam pemahaman dan pengambilan ilmu). (Nurul Badriyah, 2014)

Menurut kelompok ini, mengikuti jejak kaum salafus shalih harus dilakukan secara total, tanpa reserve, apa yang dipahami, dilakukan, dan difatwakan oleh para sahabat yang tercermin dalam diri para pemimpin agama diikuti secara utuh dan apa adannya, tidak mengurangi dan juga tidak menambah. Hal ini meliputi bidang akidah, hukum, dan tingkah laku keseharian, seperti cara berpakaian, makan, minum, dan shalat. Hal-hal inilah yang membedakan faham Ahlussunnah wal Jma'ah yang dianut FPI dan kelompok Salafi pimpinan Ja'far Umar Thalib dengan faham Ahlussunnah wal Jama'ah yang dipahami oleh kalangan NU dan Muhammadiyah.

Dalam praktek keagamaan FPI tidak ada kompromi dalam hal-hal yang bersifat aqidah, baik itu mencakup dasar kepercayaan, hubungan antar agama serta "gangguangangguan" terhadap simbol-simbol keagamaan. Jika sudah masuk kepada wilayah tersebut, maka segala upaya halal ditempuh untuk mempertahankannya. Inilah yang disebut dengan jihad atau perjuangan meninggikan kalimat Allah S.w.t di muka bumi. (Eka Hendry, 2013)

Secara umum terdapat persamaan dakwah dengan ormas Islam lain di Aceh, tetapi keunikan FPI lebih serius dan fokus dalam menegakkan syariat Islam dengan turun langsung berdakwah ke sarang-sarang maksiat. Hampir tiap malam minggu laskar FPI Banda Aceh dan Aceh Besar turun langsung menegakkan Qanun-qanun yang telah disahkan. Hal ini sebagai legitimasi Qanun Nomor 12, 13, dan 14 tahun 2003, di mana salah satu pasal menyebutkan bahwa setiap orang atau kelompok masyarakat berkewajiban menegakkan syariat Islam. Meskipun tidak diatur dalam regulasi legal-formal, FPI tetap akan berdakwah sesuai SOP

Keaktifan aktivis yang paling menarik adalah Front Pembela Islam(FPI) dalam melakukan dakwah amal ma'ruf nahi mungkarnya mempunyai cara yang berbeda dibandingkan organisasi- organisasi keagamaan pada umumnya, mereka lebih menyukai cara-cara yang nyata dalam memberantas kemaksiatan di Indonesia, misal pemberantasan perjudian, pelacuran minuman keras dan berbagai kegiatan kemaksiatan lainnya.

\section{Kerjasama FPI Aceh dengan Stake Holder}

Kerjasama FPI Aceh dengan stakeholder lainnya di Aceh selama ini cukup baik dan cenderung tidak eklusif meskipun secara umum anggota FPI dari kalangan santri ataupun alumus santri serta mantan kombatan Gerakan Aceh Merdeka (GAM). FPI cukup intens membangun komunikasi silaturrahmi dengan berbagai ormas. FPI tidak pernah membeda-bedakan ras, etnis, warna kulit, bendera, baju, dan sebagainya. Keaktifan aktivis FPI juga dapat terlihat dalam setiap even dan acara apapun yang dibuat oleh badan resmi pemerintah maupun non-pemerintah, FPI Aceh selalu hadir. Meskipun peserta yang diminta satu atau dua orang, biasanya sebagai bentuk kepedulian dan perhatian FPI khususnya terhadap isu-isu syariat Islam, aktivis FPI hadir lebih dari itu. Bahkan, tidak diundang pun akan hadir selama hal tersebut berkaitan dengan syariat Islam dan kemaslahatan umat. Bagi FPI, tidak ada disparitas dalam berdakwah, semua harus dirangkul dan bersatu meskipun cara dan metode dakwah tidak harus seragam. Yang 
penting tujuannya satu, li-i'laakalimatillaah dan mencari ridha-Nya serta hukum Islam dapat diterapkan secara kaffah di Indonesia khususnya di Aceh.

Kerjasama FPI Aceh dengan stake holder, memiliki peranan yang signifikan dalam perjalanan perkembangan organisasi FPI Aceh. Selain memiliki hubungan yang baik dengan aparatur pemerintahan, baik level propinsi, diantaranya dengan pemerintah Aceh (Gubernur dan Wakil Gubernur), insatansi pemerintahan (Dinas Syariat Islam Aceh, Kementrian Agama Aceh), serta dengan institusi kepolisian dan militer (Polda dan Kodam Iskandar Muda Aceh). Serta di level kabupaten dan kota, diantarnya dengan Pemkab (Bupati dan Wakil Bupati), Pemkot (Walikota dan Wakil Walikota), serta Dinas Syariat Islam dan Kementerian Agama baik di kabupaten maupun kotamadya. Begitu pula halnya dengan institusi kepolisian dan militer, yaitu Polres/Polresta dan Kodim. Jenjang kedekatan hubungan FPI dengan pemerintah dan institusi lainnya sampai ke jenjang paling rendah yaitu di tingkat Desa atau Gampong, yaitu Lurah atau Geuchik, tokoh Pemuda, Imam Meukim, tokoh Adat, Tuha Peut, dll. (Wawancara, Teungku Yusuf Qardhawi).

\section{PENUTUP}

Berdasarkan uraian di atas dapat disimpulkan bahwa:

a. Faktor historis FPI dideklarasikan pada 17 Agustus 1999 adalah karena merajalelanya maksiat di Ibukota Indonesia dan sekitarnya yang dilakukan secara terang-terangan dan terorganisasi dengan rapi. FPI dikenal sebagai gerakan dakwah yang bermazhab Syafi'i dalam aplikasi fikihnya, dan mengikuti metode teologi Asy'ari dan Maturidi dalam amaliyah ketauhidannya. Kehadiran FPI di Aceh ditandai hadirnya relawan kemanusian FPI yang mendirikan tenda untuk mengevakuasi jenazah korban saat harihari pertama terjadinya musibah gempa dan gelombang Tsunami 26 desember 2004 di Aceh. Selanjutnya, pada tahun 2008, kepengurusan DPW FPI Aceh terbentuk dengan terpilihnya Tgk Yusuf Qardhawi sebagai ketua umum.

b. Pemahaman gerakan dakwah FPI dilandasi oleh semangat legaliasi Surah An-Nahl ayat 125 dan Ali Imran ayat 104. Interpretasi dalil tersebut dimanifestasikan dalam bentuk melahirkan sebuah ormas militan tersistem yang bernama FPI dengan tetap menghormati penegak aparat hukum legal di Republik ini. Konsep pemahaman gerakan dakwah FPI Aceh dimplementasikan dalam bentuk wadah yang diberi nama Laskar FPI dan Laskar Peduli Islam (LPI) yang tugasnya mengawasi pelaksanaan syariat Islam ditingkat kumik dan ganpong (desa dan kelurahan).

c. Gerakan dakwah FPI Aceh, antara tantangan dan peluang. Salah satu tantangan terberat dalam dakwah FPI adalah stigma negatif yang selalu dialamatkan kepada gerakan dakwah FPI, khususnya dari media massa maintream. Hal ini berkolerasi dengan liputan media massa tersebut yang secara intensif meliput kegiatan sweeping Laskar FPI dan Laskar LPI. Semnetara kegiatan dakwah lainnya, termasuk aksi kemanusiaan jarang memperoleh tempat di pemberitaan media mainstream tersebut. Peluang dakwah FPI Aceh memiliki prospek positif, dimana terlihat dari grafik meningkatnya jumlah anggota dan kepengurusan ditingkat DPD (kabupaten), DPC (kecamatan) bahkan Ranting (Gampong/Desa). Umumnya adalah kalangan masyarakat dayah/santri yang tersebar di 23 kabupaten di Provinsi Aceh.

d. Ormas FPI memiliki strategi khusus dalam berdakwah. Strategi merupakan rukun gerakan dakwah FPI. Bagi FPI, menegakkan amar makruf dan nahi munkar tidak selama menggunakan metode seragam. Artinya, metode baku tetap menjadi pedoman, tetapi yang lebih bagi FPI adalah menerapkan strategi tebang pohon. Maksiat yang lebih besar yang harus diperioritaskan untuk didakwahkan. Apabila yang besar telah tumbang, yang kecil-kecil akan ikut menghilang dengan sendirinya. 
e. Gerakan dakwah FPI memiliki keunikan tersendiri. Dalam hal-hal tertentu berbeda dengan gerakan dakwah Islam lainnya. Dalam merekruit anggota, FPI biasanya lebih mengutamakan yang berjiwa syuja' (militan).

f. Kerjasama dengan stake-holder dan antar-organisasi dakwah bagi FPI suatu keniscayaan. Tanpa kerjasama mustahil misi akan terwujud. Kerjasama FPI dengan gerakan dakwah lainnya cukup intens dilakukan.

\section{DAFTAR PUSTAKA}

Abdullah, Wawasan Dakwah: Kajian Epistemology, Konsepsi dan Aplikasi Dakwah, Cet. II, (Medan: IAIN Press, 2002)

Achmad, Amrullah, Dakwah Islam dan Perubahan Sosial, (Yogyakarta: Prima Duta, 1983)

Awaludin, Pimay, Paradigma Dakwah Humanis Strategi dan Metode Dakwah Prof. KH. Saifuddin Zuhri, Semarang: RaSAIL, 2005.

Ghazali, Muhammad Bahri, Dakwah Komunikatif, Jakarta: Pedoman Ilmu Jaya, 1997.

Jasafat, Meniti Aktivitas Dakwah, Cet-1, Banda Aceh, Ar-Raniry Press dan Lembaga Naskah Aceh (NASA, 2012.

Dakwah Media Aktualisasi Syariat Islam, Cet-2, (Banda Aceh: Dinas Syariat Islam Provinsi Aceh, 2012),

Katsir, Ibnu, Ringkasan Ibnu Katsir (terjemahan), Jilid-2, Jakarta: Gema Insani Press, 1999.

Kirami, Abul, Merintis Jalan Dakwah di Era Globalisasi, (Surabaya: Al-Ikhlas, 2003)

Moeleong, Lexy J. Metodelogi Penelitian Kualitatif, Jakarta: Remaja Rosda Karya, 2009.

Mubarak, M Zaki, Genealogi Islam Radikal di Indonesia, Gerakan, Pemikiran dan Prospek Demokrasi, Jakarta, LP3ES, 2008

Mulkhan, Abdul Munir, Ideologisasi Gerakan Dakwah; Episode Kehidupan M. Nastir dan Azhar Basyir, Yogyakarta: Sipress, 1996.

$\mathrm{Ng}, \mathrm{Al}$-Zastrouw, Gerakan Islam Simbolik, Politik Kepentingan FPI, Yogyakarta: LkiS, 2006

Rahmat, Jalaluddin, Metode Penelitian Komunikasi, Bandung: Rosdakarya, 2004.

Rahmat, M. Imdadun, Arus Baru Islam Radikal; Transmisi Revivalisme Islam Timur Tengah, (Jakarta: Erlangga, 2005)

Rizieq, Al-Habib Muhammad, Dialag Front Pembela Islam, Amar Ma'ruf-Nahi Munkar, Menjawab berbagai tuduhan terhadap Gerakan Nasional Anti Ma'siat di indonesia, Jakarta: Ibnu Sida, 2008

Rosadi, Andi, Hitam Putih FPI: Mengungkap Rahasia-rahasia Mencengangkan Ormas Keagamaan Paling Kontroversial, (Jakarta; Kayla Pustaka, 2008) 
Sutrisno Hadi, Metode Research, Yogyakarta: Yayasan Penelitian Fakultas Psikologi UGM, 1987.

Simorangkir, Abdul Wahab, Gerakan Sosial, Studi Kasus Beberapa Perlawanan, (Yogyakarta: Pustaka Pelajar, 2007)

Usman, A. Rani, Etnis Cina Perauntauan, Di Aceh, (Jakarta: Yayasan Obor), 2009

\section{JURNAL}

Hendry Ar, Eka, Pola Gerakan islam garis Keras di Indonesia, Jurnal Khatulistiwa, STAIN Pontianak, 2013

Anwar, Saeful, Pemikran dan Gerakan Amar Ma'ruf Nahy Munkar, Front Pembela Islam di Indonesia 1989-2012, Teosofi : Jurnal Tasawuf dan Pemikiran Islam, Universitas Islam negeri Sunan Ampel, Surabaya, Volume 4, Nomor 1, Juni, 2014,

Qodir, Zuly, Gerakan Islam Politik Kontemporer di Indonesia, Makalah Yogyakarta: Pusham-UII, 2008.

\section{SKRIPSI}

Nurotul Badriyah, Amar Ma'ruh Nahi Munkar Dalam Perspektif FPI. Studi Kasus di Surabaya; Skripsi Fakultas Ushuluddin, Program Srudi Filsafat politik Islam, IAIN Sunan Ampel, Surabaya,

\section{KORAN}

Koran Tempo, 12 Januari 2005

Harian Serambi Indonesia, Edisi, Rabu 7 Januari 2015.

\section{WAWANCARA}

Wawancara penulis dengan Tgk. Muslim At- Thahiry (Ketua Umum DPD FPI Aceh Periode 2013-2017), tanggal 10 Desember 2014

Wawancara penulis dengan Tgk. Yusuf Al- Qardhawi (Ketua Umum DPD FPI Aceh Periode 2008-2012), tanggal 10 Desember 2014

Wawancara penulis dengan Tgk. Ali Hijrah (Komandan Laskar FPI), tanggal 16 Juni 2014

Wawancara penulis dengan Tgk. Mustafa Husen Woyla (Juru Bicara FPI Aceh), tanggal 5 Februari 2015 